\title{
İlginç bir vaka : Boyalı parmak
}

\author{
A strange case : The dyed finger
}

* Recep Öztürk

* Şefik Murat Arıkan

* Mehmet Akif Şimşek

** Ömer Faruk Ateş

* Ethem Toptaş

* Galip Beltir

* Dr. Abdurrahman Yurtaslan

Ankara Onkoloji Eğitim Ve

Araştırma Hastanesi,

Ortopedi ve Travmatoloji

Kliniği Ankara

** Ankara Atatürk Eğitim ve

Araştırma Hastanesi,

Radyoloji Kliniği, Ankara

\section{Öz}

Elin yüksek basınçlı enjeksiyon yaralanmaları, çok tehlikeli yaralanmalardır. Bu yazıda, sağ el 2. parmağı içerisine su bazı boya madde birikimi nedeniyle şiddetli ağrı, zonklama, ciltte gerginlik ve fonksiyon kaybı şikayetleriyle başvuran bir hasta sunulmaktadır. Postoperatif altı aylık takibinde herhangi bir komplikasyon görülmedi.

Anahtar Kelimeler: Enjeksiyon yaralanması, acil, ekstremite

\section{Abstract}

High pressure injection injuries are very dangerous type of injuries. In tis paper, we present a patient who admitted with complaints of severe pain, throbbing, tension and functional deficit at the 2 nd finger of the right hand due to water based dye accumulation into it. The patient's symptoms improved after the surgical decompression under local anesthesia in the emergency room.

No complications were observed during 6 months postoperative follow-up.

Keywords: Injection injury, emergency, extremity

\section{Giriş}

Elin yüksek basınçlı enjeksiyon yaralanmaları yabancı bir maddenin kaza ile enjeksiyonu ile oluşur (1). Bu yaralanmalar nadir olup, doku yaralanmalarının derecesi genellikle hafife alınmaktadırlar(2). Etkilenen ekstremitede sadece küçük bir giriş deliği bulunduğundan ciddiyeti tahmin etmek güçtür (3). Erken dekompresyon ve debridman prognozu olumlu etkiler. Bu tür yaralanmaya sahip hastalar dikkatlice değerlendirilmeli ve hızlı bir şekilde tedavi edilmelidirler. (1)

Bu yazıda, boya tabancası ile boya maddesinin cilt altında biriktiği ilginç ve nadir bir vaka sunulmaktadır.

Adress for correspondence: Dr. Recep Öztürk, Dr. Abdurrahman Yurtaslan Ankara Onkoloji Eğitim Ve Araştırma Hastanesi, Mehmet Akif Ersoy Mahallesi 13. Cadde No: 56 Yenimahalle /Ankara-Türkiye e-mail:ozturk_recep@windowslive.com

\section{Olgu}

26 yaşında erkek hasta acil servisimize, sağ el (hastanın nondominant eli) 2. parmağı distalinde ağrı ve zonklama ile başvurdu. Öyküsünde, yaklaşık iki saat önce, boyacı dükkanında boya tabancasını incelerken, boya tabancası ucuna sağ el 2. parmak distal falanksı volarini dayamış ve dikkatsizlik sonucu tetiğe basmış ve parmak distali 
cilt altına su bazı boya dolmuş olduğu öğrenildi.

Özgeçmişinde herhangi bir hastalığı olmadığı ve herhangi bir ilaç kullanmadığı belirlendi.

Fizik muayenede, sağ el 2. parmak distal falanks seviyesinde, şişlik, palpasyonda sertlik ve şiddetli ağrı mevcuttu. Distal falanks volar yüzeyde, orta hattın lateralinde ve tırnağa yakın lokalizasyonda yaklaşık $2 \times 2 \mathrm{~mm}$ lik giriş deliği görüldü. (şekil 1a ve 1b).

Hastanın anteroposterior ve yan direk grafisinde sağ el 2. parmak distal falanks ve orta falanks distali komşuluğunda, medialde ve ağırlıklı olarak volar yüzde, ciltaltı yumuşak doku içerisinde ağsı görünümde ince tübüler opasiteler ile 2. distal falanks komşuluğunda ciltte fokal düzensizlik görüldü
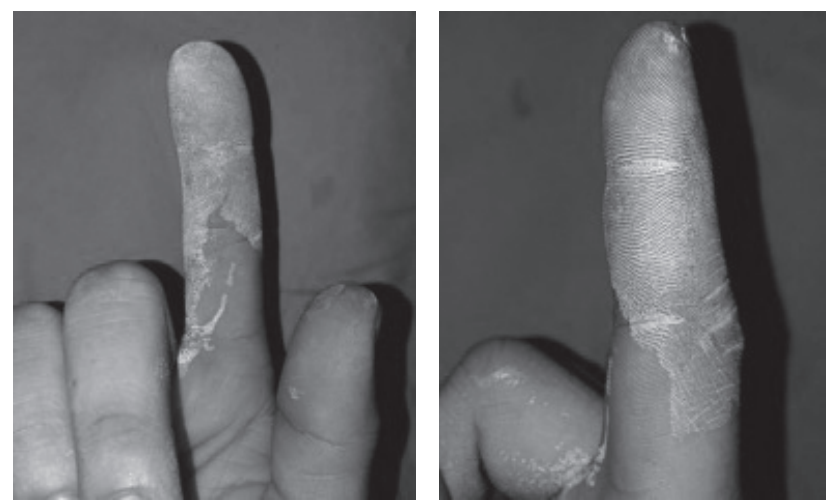

\section{Şekil 1 a,b :}

Boya tabancasına maruziyet sonrası, ekstremitenin başvuru anındaki görünümü

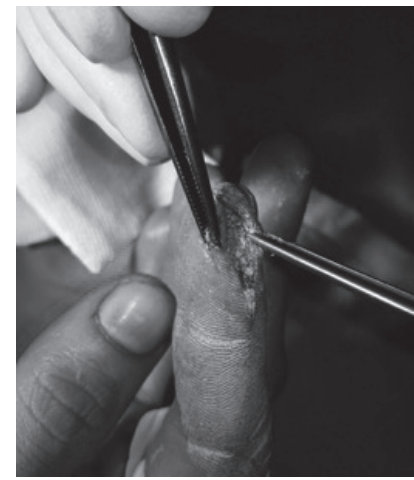

Şekil 2 :

Cilt insizyonu sonrası görünüm
(Şekil 1c ve 1d.) Ek radyolojik tetkike gerek duyulmadı.

Hastaya $1 \mathrm{~g}$ sefazolin sodyum iv ve tetanoz aşısı yapıldı. Lokal anestezi (prilokain) yapılarak, boya giriş deliği üzerinden longidutinal insizyon yapıldı ve parmak dekomprese edildi. Parmak içi dokulara boya partiküllerinin yapışık olduğu görüldü (Şekil 2). Digital damar ve sinirler ve fleksör digitorum profundus tendonu distal yapışma yeri korunarak, dokular mümkün olduğunca temizlendi (Şekil 3). Daha sonra postoperatif 2 yönlü grafi çekildi. Grafilerde cilaltı dokudaki tübüler opasilerde belirgin azalma olduğu gözlendi(Şekil 4a ve 4b).

İşlem sonrası elevasyon ve soğuk uygulama yapıldı. Lokal anestezi etkisinin sonlanması sonrası muayenede zonklama ve ağrının geçtiği görüldü. İrritan maddenin bilinmesi, 1 doz
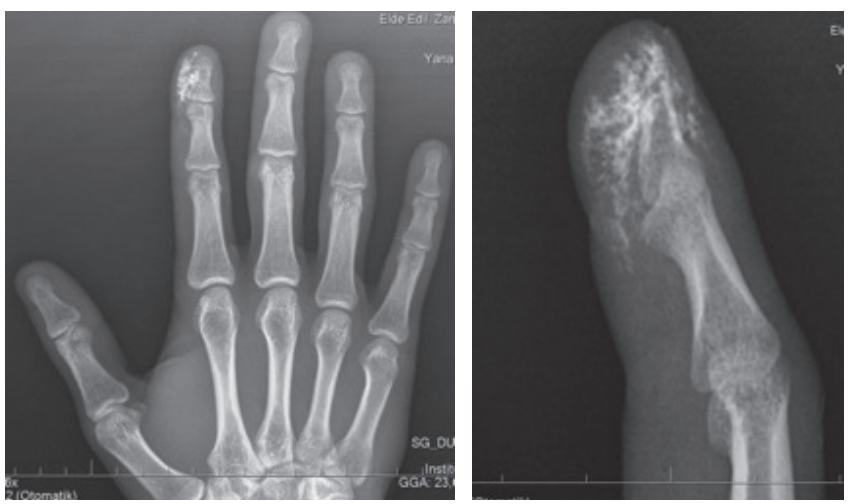

Şekil $1 \mathrm{c}, \mathrm{d}$ :

Ekstremitenin başvuru anındaki ön arka ve yan direk grafileri 

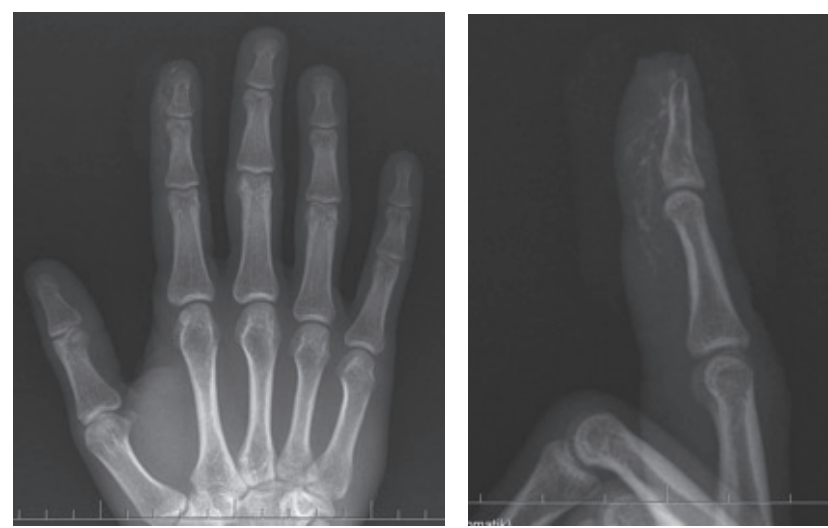

Şekil 4 a,b :

Debridman sonrası ekstremitenin ön arka ve yan grafileri

antibiyotiğin ilk 24 saat içinde yapılmış olması ve mümkün olan en erken sürede bol yıkama ve debriman yapılmış olması nedeniyle ilave antibiyotik tedavi reçete edilmedi. Hasta oral analjezik reçete edilerek taburcu edildi.

Postoperatif 20. gün poliklinik değerlendirilmesinde, yaranın tamamen iyileştiği görüldü ve dikişleri alındı. Pasif ve aktif eklem hareket açıklığı egzersizleri öğretildi. 6. ay poliklinik değerlendirilmesinde, ağrı ya da ek semptom olmadığı, eklem hareketlerinin tamamen açık olduğu görüldü.

\section{Tartışma}

Elin yüksek basınçlı enjeksiyon yaralanmaları nadirdir(1). Sıklıkla 21-59 yaş arası erkeklerde, nondominant elde ve indeks parmakta görülür $(4,5)$. Bizim vakamızda da, literatürle uyumlu olarak 26 yaşında erkek hastada nondominant el indeks parmak lezyonu mevcuttu.

En sık enjekte edilen maddeler yağ, boya ve tiner olmakla birlikte literatürde onlarca farklı madde enjeksiyon yaralanmaları bildirilmiştir (5). Bizim vakamız da boya enjeksiyonu yaralanması idi.

Enjeksiyon yaralanmalarında, etkilenen ekstremitede sadece küçük bir giriş deliği bulunduğundan ciddiyeti tahmin etmek güçtür, bu yüzden hafif bir lezyon görünümü oluşturabilir, ancak ciddi dolaşım bozukluğa ve sekonder enfeksiyon gibi ağır tablolar oluşturabilir(6). Bu nedenle, irritan maddenin tipine, miktarına ve lokalizasyonuna göre, antibiyoterapi uygulanabilir (7).

Enjekte edilen maddenin türüne bağlı olarak, o lokalizasyonda birkaç saat içinde şişlik ve ağrı görülebilir. Bizim vakamızda da, hastanın başvuru şikayetleri etkilenen bölgede şişlik ve ağrı idi.

Enjekte edilen irritan madde, fasial planlar boyunca proksimale ilerleyerek, vasküler kompresyon ve fokal nekroza neden olabilir(8). En önemli prognostik faktörler, yaralanma ile cerrahi müdahale arası süre ve irritan maddenin türüdür . Boya ve tiner en toksik ajanlar olarak bildirilmiştir. (5). Hastaya ait faktörler ve yabancı cisimlerin farklı tiplerinin karakteristikleri, yabancı cisim çıkarımının aciliyeti ve gerekliliğini belirlemede önemlidir. Daha açık bir ifade ile, vücuda giren tüm yabancı cisimlerin çıkarılması gerekmez (9). Ancak elin yüksek basınç yaralanmaları cerrahi bir acildir ve hastayı gözlem odasında takibe almak, katastrofik sonuçlara yol açabilir (5) Bizim olgumuzda boya enjeksiyonu gibi ciddi bir yaralanma olmasına rağmen, yapılan erken cerrahi müdahale ile iyi bir prognoz elde edilmiştir. Bu açıdan, cerrahi müdahalenin erken dönemde yapılmasının prognozu olumlu etkilediğini söyleyebiliriz.

Elde yüksek basınçlı enjeksiyon yaralanması olan bütün hastalarda, dikkatli bir fizik muayene sonrası, mutlaka iki yönlü direk grafileri içeren radyolojik değerlendirme yapılmalı ve lezyonun yaygınlığı belirlenmelidir (10). Bizim çalışmamızda, preoperatif iki yönlü direk grafi lezyonun yaygınlığını değerlendirmede yeterli olmuş, ek radyolojik tetkik istenmemiştir.

İhmal edilen bir irritan madde/yabancı cisim varlığı; enfeksiyon haricinde ağrı, fonksiyon kaybı, eklem hasarı, tenosinovit, tendon rüptürü ve osteomyeliti de içeren komplikasyonlara yol açabilir (11). Bizim çalışmamızda akut dönemde gerekli operasyon uygulandığı için, bu komplikasyonların hiçbirine rastlanmadı.

Subkutan dokudan yabancı cisimlerin çıkarımı, eksik planlama yapıldığında, zaman alıcı ve sinir bozucu olabilir. Yabancı cisimlerin başarılı çıkarımı; öykünün iyi alınması ve dikkatli bir fizik muayene, uygun görüntüleme, yeterli Işık, anestezi, exposure, hemostaz, hasta kooperasyonu, çıkarma teşebbüsü için kesintisiz süre, uygun yara bakımı ve postoperatif iyi takip gerektirir (9).

Bizim olgumuzda, preoperatif dönemde iyi bir planlama yapılmıştır. Önce öykü ve fizik muayene, daha sonra radyoopak yabancı cisim için iki yönlü direk grafi değerlendirilmiş, daha sonra acil servis cerrahi müdahale odasında, lokal anestezi altında, portable cerrahi masa ışığı kullanılarak dekompresyon ve debridman yapılmış, hastanın postoperatif takibi yapılmış ve hastanın takibinde herhangi bir komplikasyon görülmemiştir. 


\section{Sonuç}

Elin yüksek basınçlı enjeksiyon yaralanmaları, başvuru anında önemsiz gibi bir tablo sergileyen, ancak ciddi komplikasyonlara yol açabilen vakalardır. Uygun olan yaklaşım, olguların ilk aşamada bekletilmeden dikkatlice değerlendirilmesi, mümkün olan en erken sürede cerrahi müdahalenin yapılması ve sonrasında uygun takiptir.

\section{Kaynaklar}

1- Rees CE. Penetration of tissue by fuel oil under high pressure from diesel engine. JAMA 1937; 109: 866-7.

2- Rappold G, Rosenmayr E. High-pressure injection injuries of the hand. Pathogenesis, problems and therapy. Handchir Mikrochir Plast Chir. 2001; 33: 332-41.

3- Verhoeven N, Hierner R. High-pressure injection injury of the hand: an often underestimated trauma: case report with study of the literature. Strategies Trauma Limb Reconstr. 2008; 3: 27-33

4- Efeoğlu M, Eroğlu SE, Ömercikoğlu S, Akoğlu H, Onur Ö, Denizbaşı A. High-Pressure Liquid Crystal Injection Injury of the Hand: Case Report. JAEMCR 2014; 5: 158-60.

5- Ertaş NM, Gündeşlioğlu Ö, Çelebioğlu S. Elin Yüksek Basınçlı Enjeksiyon Yaralanmaları. T Klin Tıp Bilimleri. 2001;21:329-331.

6- Hart RG, Smith GD, Haq A. Prevention of high-pressure injection injuries to the hand. Am J Emerg Med. 2006; 24: 73-6. 7- Sirio CA, Smith JS Jr, Graham WP. High-pressure injection injuries of the hand. A review. Am Surg 1989; 55 : 714-8.

8- O'Sullivan ST, O'Donoghue JM, O'Connor TPF. Occupational highpressure injection injury of the hand. Dermatology 1997; 194:311.

9- Reichman E.F. Reichman, Eric F. "Chapter 97. Subcutaneous Foreign Body Identification and Removal." Emergency Medicine Procedures, 2e. Reichman EF 10-Ozturk R. Kemik ve Yumuşak doku Tümörleri. Atay T, editör. Ortopedi ve Spor Yaralanmaları Asistan Kitabı (1. Baskı). Ankara Derman Tıbbi Yayıncılık; 2015 :635-704.

11- 7 Lammers RL: Soft tissue foreign bodies. Ann Emerg Med 1988;17(12):1336-1347 